Results: 888 patients with RA with 3,396 follow-up visits were included in the study. 13,636 daily air pollution records were retrieved. We found an exposure-response relationship between the concentration of air pollutants and the risk of having abnormal CRP levels (Figure 1). Patients exposed to greater concentrations of air pollutants were at higher risk of having CRP levels $\geq 5 \mathrm{mg} / \mathrm{L}$. Patients exposed to PM10 concentrations $\geq 50 \mu \mathrm{g} / \mathrm{m} 3$ had a $70 \%$ higher risk of having CRP levels $\geq 5 \mathrm{mg} / \mathrm{L}$ (OR 1.696 95\% Cl, 1.245-2.311). Among RA patients, 440 patients (49.5\%) had at least 2 follow-up visits with a difference in DAS28-CRP of more than 1.2 points (with current DAS28-CRP $\geq 3.2$ ), serving as our sample for the case-crossover study. Concentrations of $\mathrm{CO}, \mathrm{NO}$, NO2, NOx, PM10, PM2.5 and $\mathrm{O} 3$ were higher in the 60-day period preceding a flare (Table 1). Sensitivity analyses considering geometric mean and cumulative concentrations yielded similar results (data not shown). Remarkably, we found that the cumulative exposure to NO2 in the 60 days preceding a flare was approximately $500 \mu \mathrm{g} / \mathrm{m} 3$ higher than the low disease activity visit, an exposure that equates to approximately to 200 passively smoked cigarettes (3.5 cigarettes per day on a 60-day period).

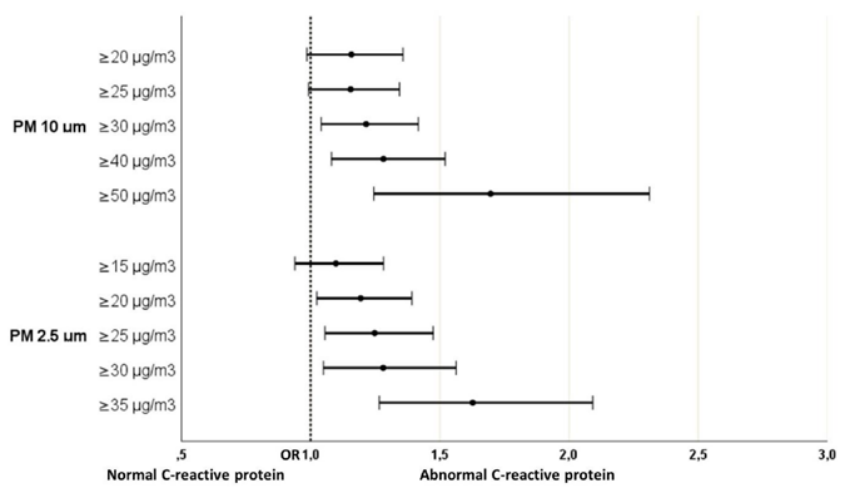

Figure 1. Odds of having abnormal CRP serum levels $(\geq 5 \mathrm{mg} / \mathrm{L})$ at different exposures of PM10 and PM2.5 (mean concentration in the 60 days before assessment)

Table 1. Case-crossover study. Mean concentrations (mean and Area Under the Curve) of air pollutants in the 60 days before low-disease activity visit and flare visit (DAS28-CRP difference >1.2)

\begin{tabular}{|c|c|c|c|c|}
\hline Pollutant & & $\begin{array}{l}\text { Control period (low disease } \\
\text { activity, } n=440 \text { ) }\end{array}$ & $\begin{array}{l}\text { Hazard period } \\
\text { (flare, } \mathrm{n}=440)\end{array}$ & $\begin{array}{c}p \\
\text { value }\end{array}$ \\
\hline \multirow[t]{2}{*}{$\mathrm{CO} \mu \mathrm{g} / \mathrm{m}^{3}$} & Mean & 0.38 & 0.42 & 0.001 \\
\hline & AUC & 22.00 & 24.53 & 0.001 \\
\hline \multirow[t]{2}{*}{$\mathrm{NO} \mu \mathrm{g} / \mathrm{m}^{3}$} & Mean & 19.23 & 24.11 & 0.002 \\
\hline & AUC & $1,120.53$ & $1,403.88$ & 0.002 \\
\hline \multirow{2}{*}{$\mathrm{NO}_{2} \mu \mathrm{g} / \mathrm{m}^{3}$} & Mean & 30.91 & 32.44 & 0.042 \\
\hline & AUC & $1,800.96$ & $1,892.05$ & 0.040 \\
\hline \multirow{2}{*}{$\mathrm{NO}_{x} \mu \mathrm{g} / \mathrm{m}^{3}$} & Mean & 60.34 & 69.35 & 0.004 \\
\hline & AUC & $3,515.77$ & $4,041.06$ & 0.004 \\
\hline \multirow[t]{2}{*}{$\mathrm{PM} 10 \mu \mathrm{g} / \mathrm{m}^{3}$} & Mean & 31.21 & 33.65 & 0.011 \\
\hline & AUC & $1,789.22$ & $1,942.52$ & 0.005 \\
\hline \multirow{2}{*}{$\mathrm{O}_{3} \mu \mathrm{g} / \mathrm{m}^{3}$} & Mean & 31.08 & 33.79 & 0.002 \\
\hline & AUC & $1,776.37$ & $1,934.35$ & 0.001 \\
\hline \multirow[t]{2}{*}{ PM2. $5 \mu \mathrm{g} / \mathrm{m}^{3}$} & Mean & 23.08 & 24.74 & 0.018 \\
\hline & AUC & $1,272.61$ & $1,403.60$ & $<0.001$ \\
\hline
\end{tabular}

Conclusion: We found a striking association between air pollution and RA disease severity and reactivations in a cohort of patients followed over a 5-year period. The exposure to high levels of air pollutants was associated with increased CRP levels and a higher risk of experiencing a flare of arthritis. This excessive risk was evident at very low levels of exposure, even below the proposed threshold for the protection of human health. Our study has important and direct consequences. In order to reduce the burden of RA, public and environmental health policy makers should aim to diminish gaseous and PM emissions to a larger extent as currently recommended. Disclosure of Interests: None declared

DOI: 10.1136/annrheumdis-2021-eular.216

\section{OP0179 DISCONTINUATION RATE OF TOFACITINIB IS SIMILAR WHEN COMPARED TO TNF INHIBITORS IN RHEUMATOID ARTHRITIS PATIENTS: POOLED DATA FROM TWO RHEUMATOID ARTHRITIS REGISTRIES IN CANADA}

M. Movahedi ${ }^{1}$, D. Choquette ${ }^{2}$, L. Coupal ${ }^{2}$, A. Cesta ${ }^{1}$, X. LI ${ }^{1}$, E. Keystone ${ }^{3}$, C. Bombardier ${ }^{1}$ on behalf of OBRI and RHUMADATA Investigators. ${ }^{1} \mathrm{UHN}$, Toronto General Hospital Research Institute, Toronto, Canada; ${ }^{2}$ Institut de Rhumatologie de Montréal, RHUMADATA, Montreal, Canada; ${ }^{3}$ University of Toronto, Medicine, Toronto, Canada

Background: Tofacitinib (TOFA) is an oral, small molecule drug used for rheumatoid arthritis (RA) treatment as the first or an alternative option to biologic disease- modifying antirheumatic drugs (bDMARDs), including tumor necrosis factor inhibitors (TNFi). The similarity in retention of TNFi and TOFA was previously reported separately by the Ontario Best Practices Research Initiative (OBRI) and the Quebec cohort RHUMADATA ${ }^{\circledR}$.

Objectives: To increase the study power, we propose to evaluate the discontinuation rate (due to any reason) of TNFi compared to TOFA, using pooled data from both these registries.

Methods: RA patients enrolled in the OBRI and RHUMADATA initiating their TOFA or TNFi between $1^{\text {st }}$ June 2014 (TOFA approval date in Canada) and $31^{\text {st }}$ Dec 2019 were included. Time to discontinuation was assessed using adjusted Kaplan-Meier (KM) survival and Cox regression models. To deal with confounding by indication, we estimated propensity scores for covariates with a standard difference greater than 0.1 . Models were then adjusted using stratification and inverse probability of treatment weight (IPTW) methods. Multiple imputation (Imputation by Chained Equation method, $\mathrm{N}=20$ ) was used to deal with missing data for covariates at treatment initiation.

Results: A total of 1318 patients initiated TNFi $(n=825)$ or TOFA $(n=493)$ with mean (SD) disease duration of 8.9 (9.3) and 13.0 (10.1) years, respectively. In the TNF group, $78.8 \%$ were female and mean age (SD) at treatment initiation was 57.6 (12.6) years. In the TOFA group, $84.6 \%$ were female and mean (SD) age at treatment initiation was 59.5 (11.5) years. The TNFi group was less likely to have prior biologic use $(33.9 \%)$ than the TOFA group $(66.9 \%)$. At treatment initiation, the mean (SD) CDAI was significantly $(p<0.05)$ lower in the TNFi group [20.0 (11.7)] compared to the TOFA group [22.1(12.4)]. Physical function measured by HAQ-DI was also significantly lower $(p<0.05)$ in the TNFi compared to the TOFA group (1.2 vs.1.3).

Over a mean follow-up of 23.2 months, discontinuation was reported in 309 $(37.5 \%)$ and $182(36.9 \%)$ of all TNFi and TOFA patients, respectively. After adjusting for propensity score deciles across 20 imputed datasets, there was no significant difference in discontinuation between treatment groups (adjusted HRs: $0.96,95 \% \mathrm{Cl}: 0.78-1.18 ; \mathrm{p}=0.69$ ). The results were similar for two propensity adjustment methods. Figure 1 shows IPTW adjusted KM survival curves comparing discontinuation rates in patients treated with TNFi and TOFA.

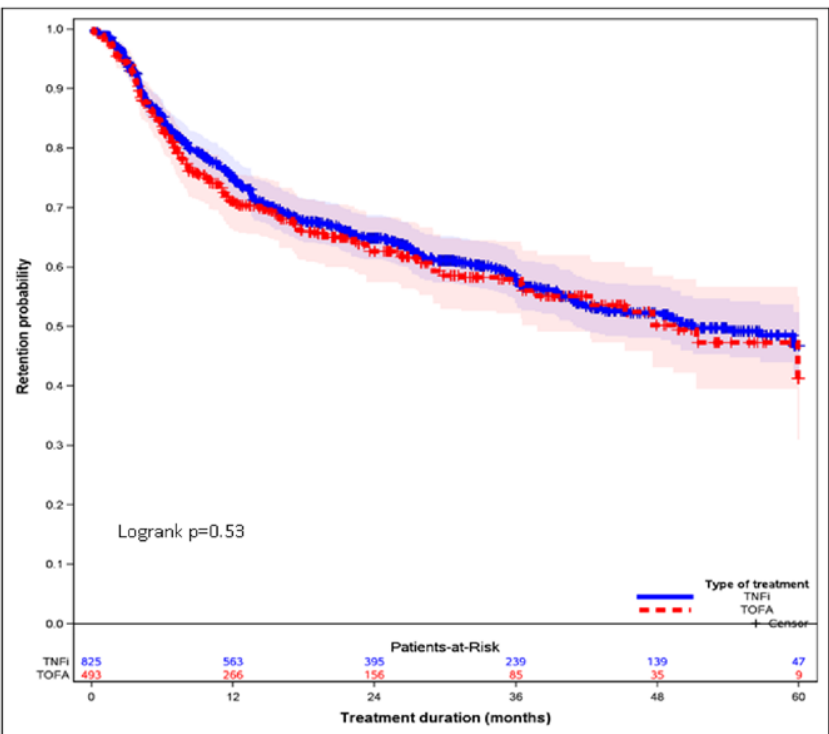

Figure 1. Note: Propensity Score Weighted (IPTW) Survival Curves was performed using one imputed dataset

Conclusion: In this pooled real -world data study, we found that TNFi and TOFA retention is similar in patients with RA. In the next step we will analysis the data for specific reasons of dicontinutaion. We will also repeat analysis comparing discontinuation in the first users versus those after one or more biologic failure. Disclosure of Interests: Mohammad Movahedi: None declared, Denis Choquette Grant/research support from: Rhumadata ${ }^{\circledR}$ is supported by unrestricted grants from Abbvie Canada, Amgen Canada, Eli Lilly Canada, Novartis Canada, Pfizer Canada, Sandoz Canada and Sanofi Canada., Louis Coupal: None declared Angela Cesta: None declared, Xiuying Li: None declared, Edward Keystone Grant/research support from: Amgen, Merck, Pfizer Pharmaceuticals, PuraPharm. Speaker Honoraria Agreements: AbbVie, Amgen, Bristol-Myers Squibb Company, Celltrion, Myriad Autoimmune, F. Hoffmann-La Roche Inc, Gilead, Janssen Inc, Lilly Pharmaceuticals, Merck, Pfizer Pharmaceuticals, Sandoz, Sanofi-Genzyme, Samsung Bioepsis. Consulting Agreements/Advisory Board Membership: AbbVie, Amgen, Bristol-Myers Squibb Company, Celltrion, Myriad Autoimmune, F. Hoffmann-La Roche Inc, Gilead, Janssen Inc, Lilly Pharmaceuticals, Merck, Pfizer Pharmaceuticals, Sandoz, Sanofi-Genzyme, Samsung Bioepsis, Claire Bombardier Grant/research support from: OBRI was funded by peer reviewed grants from CIHR (Canadian Institute for Health Research), Ontario Ministry of Health and Long-Term Care (MOHLTC), Canadian Arthritis Network (CAN) and unrestricted 
grants from: Abbvie, Amgen, Aurora, Bristol-Meyers Squibb, Celgene, Hospira, Janssen, Lilly, Medexus, Merck, Novartis, Pfizer, Roche, Sanofi, \& UCB. Dr. Bombardier held a Canada Research Chair in Knowledge Transfer for Musculoskeletal Care and a Pfizer Research Chair in Rheumatology DOI: 10.1136/annrheumdis-2021-eular.912

\section{OP0180 \\ IMPACT OF RF AND ANTI-CITRULLINATED PROTEIN ANTIBODY SEROSTATUS ON 2-YEAR RETENTION OF ABATACEPT IN PATIENTS WITH RA}

$\underline{\text { R. Alten }}{ }^{1}$, X. Mariette ${ }^{2}$, R. M. Flipo ${ }^{3}$, R. Caporali ${ }^{4,5}$, M. H. Buch ${ }^{6,7}$, Y. Patel $^{8}$, R. Sanmartí ${ }^{9}$, S. Marsal ${ }^{10}$, M. T. Nurmohamed ${ }^{11}$, H. Griffiths $^{12}$, P. Peichl $^{13}$, B. Bannert ${ }^{14}$, A. Forster ${ }^{15}$, M. Chartier ${ }^{16}$, S. Connolly ${ }^{17}$, Y. Elbez ${ }^{18}$, C. Rauch ${ }^{19}$, V. Khaychuk ${ }^{20}$, K. Lozenski ${ }^{21}$. ${ }^{1}$ Schlosspark-Klinik University, Department of Internal Medicine, Rheumatology, Berlin, Germany; ${ }^{2}$ Université Paris-Saclay, AP-HP, Hospital Bicêtre, Department of Rheumatology, Paris, France; ${ }^{3}$ Centre Hospitalier Universitaire de France, Department of Rheumatology, Lille, France; ${ }^{4}$ University of Milan, Department of Clinical Sciences and Community Health, Milan, Italy; ${ }^{5} \mathrm{G}$. Pini Hospital, Clinical Rheumatology Unit, Milan, Italy; ${ }^{6}$ University of Leeds, Leeds Institute for Rheumatic and Musculoskeletal Medicine, Leeds, United Kingdom; ${ }^{7}$ University of Manchester, Division of Musculoskeletal \& Dermatological Sciences, Manchester, United Kingdom; ${ }^{8}$ Hull Royal Infirmary, Rheumatology, Hull, United Kingdom; ${ }^{9}$ Hospital Clinic de Barcelona, Rheumatology Department, Barcelona, Spain; ${ }^{10}$ Hospital Universitari Vall d'Hebron, Rheumatology, Barcelona, Spain; ${ }^{11}$ ARC Amsterdam University Hospitals - VU University Medical \& Reade, Department of Rheumatology, Amsterdam, Netherlands; ${ }^{12}$ University Hospital Geelong, Barwon Rheumatology Service, Geelong, Australia; ${ }^{13}$ Evangelical Hospital, Department of Internal Medicine, Vienna, Austria; ${ }^{14}$ Universitätsspital Basel, Rheumatologische Universitätsklinik, Basel, Switzerland; ${ }^{15}$ Schulthess Klinik, Department of Rheumatology, Zürich, Switzerland; ${ }^{16}$ Bristol Myers Squibb, Non-Registrational Data Generation, Rueil-Malmaison, France; ${ }^{17}$ Bristol Myers Squibb, Global Drug Development, Princeton, United States of America; ${ }^{18}$ Deepscover, Biostatistics, Puteaux, France; ${ }^{19}$ Bristol Myers Squibb, Medical Immunology \& Fibrosis, Munich, Germany; ${ }^{20}$ Bristol Myers Squibb, US Medical Immunology and Fibrosis, Princeton, United States of America; ${ }^{21}$ Bristol Myers Squibb, Immunology and Fibrosis, Princeton, United States of America

Background: Up to $50 \%$ of patients with RA discontinue DMARD treatment within 18 months. ${ }^{1}$ However, up to $20 \%$ of patients who fail multiple treatments may have a good treatment response to another therapy. ${ }^{1}$ Predictive biomarkers, such as RF and anti-citrullinated protein antibodies (ACPAs), may be useful to stratify patients with RA to the most appropriate treatment. ${ }^{1}$ ASCORE (Abatacept SubCutaneOus in Routine Clinical PracticE; NCT02090556) was a 2-year, observational, prospective, multicentre study of SC abatacept for the treatment of RA in routine clinical practice. ${ }^{2}$ Objectives: To determine if RF/ACPA serostatus and treatment line impact abatacept retention in patients with RA in a post hoc analysis of ASCORE.

Methods: Eligible patients, aged $\geq 18$ years, with active moderate-to-severe RA (ACR/EULAR 2010 criteria) who were IV abatacept-naive and initiated SC abatacept $125 \mathrm{mg}$ once weekly, were enrolled into two cohorts: biologic (b) DMARD-naive patients and those with $\geq 1$ prior bDMARD treatment failure. This post hoc analysis assessed abatacept retention rate at 2 years in a subset of patients with RF/ACPA serostatus data $(n=1748)$ from the ASCORE study ( $N=2892$; as observed). Baseline $(B L)$ serostatus groups examined by treatment line were: RF/ACPA double positive $(+/+)$ RA, RF/ACPA single positive (RF+/ACPA- or RF-/ACPA+) RA (data not shown) and RF/ACPA double negative (-/-) RA. Last observation carried forward (LOCF) analyses were used to assess change from $B L$ and measures of disease remission (DAS28 $[C R P]<2.6, C D A I \leq 2.8$, and $S D A I \leq 3.3$ ) in patients with +/+ RA versus -/ $-R A$. Results: BL demographic and disease characteristics were similar across serostatus groups and treatment lines (Table 1). Mean age was 57.1 and 57.8 years for +/+ RA and -/- RA, respectively. Mean DAS28 (CRP) was 4.7 and 4.8 for +/+ RA and -/- RA, respectively. In patients with +/+ RA, abatacept retention was greater when given as first-line treatment $(57 \%$ vs $48 \%$ when given as $\geq$ second-line) (Figure 1). Retention was similar in patients with -/-RA regardless of treatment line. After 2 years, mean (SE) change from BL (LOCF) in DAS28 (CRP) was $-1.41(0.06)$ and -0.97 (0.09) for patients with +/+ and -/- RA, respectively. For patients with $+/+\mathrm{RA}$, mean (SE) change from BL in DAS28 (CRP) was -1.62 $(0.08)$ for those in whom abatacept was first-line and $-1.19(0.08)$ for those in

Table 1. BL demographics and disease characteristics by RF/ACPA status

\begin{tabular}{lcccc}
\hline & \multicolumn{2}{c}{$\begin{array}{c}+/+\mathrm{RA} \\
(\mathbf{n}=\mathbf{1 0 7 9})\end{array}$} & \multicolumn{2}{c}{$\begin{array}{c}\text { l- RA } \\
(\mathbf{n}=\mathbf{3 4 3})\end{array}$} \\
\cline { 2 - 5 } & $\begin{array}{c}\text { First-line } \\
(\mathbf{n}=511)\end{array}$ & $\begin{array}{c}\geq \text { second-line } \\
(\mathbf{n}=568)\end{array}$ & $\begin{array}{c}\text { First-line } \\
(\mathbf{n}=140)\end{array}$ & $\begin{array}{c}\geq \text { second-line } \\
(\mathbf{n}=\mathbf{2 0 3})\end{array}$ \\
\hline Age & $57.1(13.4)$ & $57.1(12.2)$ & $59.5(14.7)$ & $56.6(13.2)$ \\
DAS28 (CRP) & $4.7(1.2)$ & $4.7(1.2)$ & $4.8(1.1)$ & $4.8(1.2)$ \\
CDAI & $26.6(12.5)$ & $26.6(12.4)$ & $27.7(12.5)$ & $28.6(13.8)$ \\
SDAl & $28.1(13.1)$ & $28.1(12.9)$ & $29.1(12.9)$ & $30.2(14.7)$ \\
\hline
\end{tabular}

Data are mean (SD). Patients with missing data for BL RF/ACPA status are excluded.ACPA=anti-citrullinated protein antibody; $\mathrm{BL}=$ baseline. whom abatacept was $\geq$ second-line. For patients with $-/-$ RA, mean (SE) change from BL in DAS28 (CRP) was -1.03 (0.13) for those in whom abatacept was firstline and $-0.93(0.12)$ for those in whom abatacept was $\geq$ second-line. Remission rates (LOCF) were significantly $(\mathrm{p}<0.0001)$ higher in patients with $+/+\mathrm{RA}$ vs -1 RA respectively: DAS28 (CRP) $38.4 \%(n=393)$ versus $19.3 \%(n=62)$; CDAI 50.6\% $(n=513)$ versus $33.0 \%(n=107)$; and SDAI $49.5 \%(n=497)$ versus $32.5 \%(n=102)$. Conclusion: In this real-world analysis, patients with +/+ RA treated with firstline abatacept had higher retention than patients receiving abatacept as $a \geq$ second-line therapy. Remission rates on abatacept were higher in patients with $+/+$ RA versus -/- RA. These results support early treatment with abatacept and highlight the importance of further evaluating precision medicine approaches in RA.

\section{REFERENCES:}

[1] Smolen JS, et al. Ann Rheum Dis 2020;79:685-699.

[2] Alten R, et al. Ann Rheum Dis 2019;78(suppl 2):A1639.

Figure 1. Retention rates by treatment group in patients with $+/+$ RA

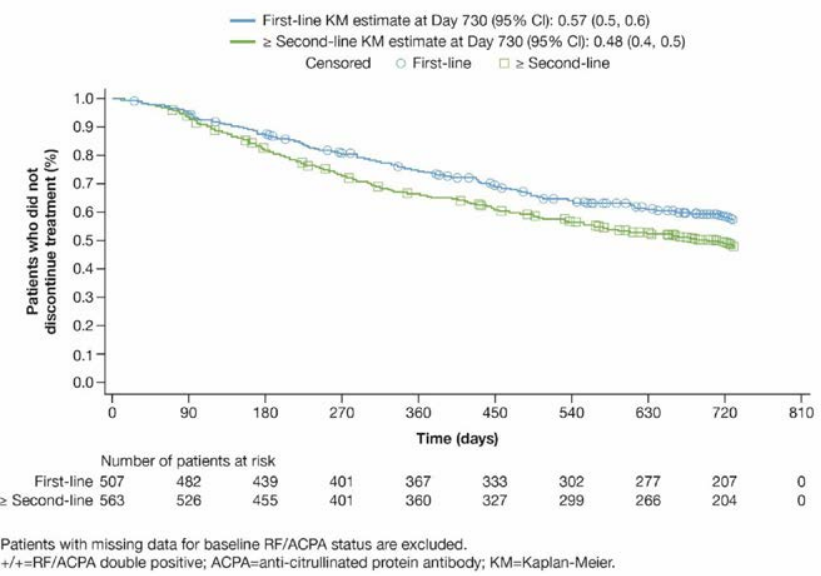

Acknowledgements: Professional medical writing and editorial assistance was provided by Lindsay Craik at Caudex and was funded by Bristol Myers Squibb. This study was funded by Bristol Myers Squibb.

Disclosure of Interests: Rieke Alten Speakers bureau: AbbVie, Bristol Myers Squibb, Gilead, Janssen, Lilly, Pfizer, Consultant of: AbbVie, Bristol Myers Squibb, Gilead, Janssen, Lilly, Pfizer, Grant/research support from: AbbVie, Bristol Myers Squibb, Gilead, Janssen, Lilly, Pfizer, Xavier Mariette Consultant of: Bristol Myers Squibb, Galapagos, Gilead, GlaxoSmithKline, Janssen, Pfizer, UCB, Rene-Marc Flipo Speakers bureau: AbbVie, Bristol Myers Squibb, Janssen, Lilly, Medac, Merck Sharp \& Dohme, Novartis, Pfizer, Roche-Chugai, Grant/research support from: Amgen, Janssen, Novartis, Pfizer, Roberto Caporali Speakers bureau: AbbVie, Amgen, Bristol Myers Squibb, Celltrion, Fresenius Kabi, Galapagos, Gilead, Lilly, Merck Sharp \& Dohme, Pfizer, Roche, Samsung Bioepis, Sanofi, UCB, Consultant of: Galapagos, Gilead, Janssen, Lilly, Merck Sharp \& Dohme, Maya H Buch Speakers bureau: AbbVie, Consultant of: AbbVie, Eli Lilly, Gilead, Merck Serono, Pfizer, Roche, Sanofi, Grant/research support from: Gilead, Pfizer, Roche, UCB, Yusuf Patel: None declared, Raimón Sanmartí Speakers bureau: AbbVie, Bristol Myers Squibb, Gebro, Janssen, Lilly, Merck Sharp \& Dohme, Pfizer, Roche, Sanofi, Consultant of: AbbVie, Bristol Myers Squibb, Gebro, Lilly, Merck Sharp \& Dohme Pfizer, Roche, Sanofi, Grant/research support from: Bristol Myers Squibb, Merck Sharp \& Dohme, Pfizer, Sara Marsal Speakers bureau: Bristol Myers Squibb, Celgene, Pfizer, Roche, Sanofi, UCB, Consultant of: AbbVie, Bristol Myers Squibb, Celgene, Galapagos, Merck Sharp \& Dohme, Pfizer, Roche, Sanofi, UCB, Grant research support from: AbbVie, Bristol Myers Squibb, Celgene, Janssen, Merck Sharp \& Dohme, Novartis, Pfizer, Roche, Sanofi, UCB, M.T. Nurmohamed Speak ers bureau: AbbVie, Bristol Myers Squibb, Eli Lilly, Roche, Sanofi, Consultant of: AbbVie, Celgene, Celltrion, Eli Lilly, Janssen, Grant/research support from: AbbVie, Bristol Myers Squibb, Celgene, Eli Lilly, Janssen, Merck Sharp \& Dohme, Mundipharma, Novartis, Pfizer, Roche, Sanofi, Hedley Griffiths Consultant of: AbbVie, Gilead, Janssen, Novartis, Peter Peichl: None declared, Bettina Bannert: None declared, Adrian Forster: None declared, Melanie Chartier Shareholder of: Bristol Myers Squibb, Employee of: Bristol Myers Squibb, Sean Connolly Shareholder of: Bristol Myers Squibb, Employee of: Bristol Myers Squibb, Yedid Elbez Consultant of: Bristol Myers Squibb, Christiane Rauch Shareholder of: Bristol Myers Squibb Employee of: Bristol Myers Squibb, Vadim Khaychuk Shareholder of: Bristol Myers Squibb, Employee of: Bristol Myers Squibb, Karissa Lozenski Shareholder of: Bristol Myers Squibb, Employee of: Bristol Myers Squibb

DOI: 10.1136/annrheumdis-2021-eular.932 